\title{
LIBERALISASI PERDAGANGAN SEKTOR JASA TRANSPORTASI UDARA ASEAN DAN ASEAN FTA PARTNERS: MODEL IC-IRTS CGE
}

\author{
Trade Liberalization of Air Transport Service Sector in ASEAN and \\ The ASEAN FTA Partner: The CGE-IRTS Model
}

\author{
Widyastutik \\ Departemen Ilmu Ekonomi, Fakultas Ekonomi dan Manajemen, Institut Pertanian Bogor \\ Jl. Agatis, Kampus IPB Dramaga Bogor, Jawa Barat, 16680, Indonesia
}

Naskah diterima: 01/02/2019; Naskah direvisi: 16/11/2019; Disetujui diterbitkan: 06/05/2020; Dipublikasikan online: 15/07/2020

\begin{abstract}
Abstrak
Pertumbuhan populasi, peningkatan kesejahteraan ekonomi serta letak geografis Indonesia yang unik meningkatkan "kecenderungan untuk melakukan penerbangan". Dengan pertimbangan tersebut, jasa transportasi udara merupakan sarana yang amat penting dan efisien dalam menghubungkan hampir 240 juta penduduk Indonesia, maupun penduduk di belahan dunia lainnya. Seperti pada sektor jasa lainnya, hambatan perdagangan di sektor jasa transportasi udara diimplementasikan melalui kebijakan pemerintah melalui berbagai regulasi. Hal ini menyebabkan berbagai regulasi menjadi penghambat karena regulasi tersebut meningkatkan biaya transaksi yang pada akhirnya dibebankan ke konsumen dalam bentuk harga jasa yang lebih tinggi. Penelitian ini bertujuan untuk (1) mengestimasi tarif ekuivalen dari NTBs dan (2) menganalisis dampak eliminasi hambatan regulasi di sektor jasa transportasi udara dalam lingkup ASEAN dan ASEAN FTA Partners. Dengan menggunakan model gravity, teridentifikasi bahwa hambatan perdagangan di jasa transportasi udara ASEAN dan ASEAN FTA Partners masih relatif tinggi yaitu antara $0-11.2 \%$. Dengan menggunakan CGE model IC-IRTS, simulasi GTAP menunjukkan bahwa hasil penelitian ini konsisten dengan teori pro-kompetitif. Gain yang lebih besar diperoleh dari model CGE yang menggunakan asumsi IC-IRTS dibandingkan PC-CRTS. Dengan asumsi IC-IRTS, China memperoleh manfaat yang lebih besar yang diindikasikan dengan peningkatan kesejahteraan paling tinggi.
\end{abstract}

Kata Kunci: Jasa Transportasi Udara, Hambatan Non Tarif, Model IC-IRTS CGE, Model Gravitasi

\begin{abstract}
Population growth, increased economic welfare, and Indonesia's unique geographical location increase the "tendency to travel by air transportation". Based on these conditions, air transport is a fundamental and efficient way to connect almost 240 million Indonesians, and people in other parts of the world. However, like other service sector, trade barriers in the air transportation service is implemented through government policies through regulations. This condition causes the regulations to be barriers because they increase transaction costs charged to consumers in the form of higher service prices. This study aims to (1) estimate the tax-equivalent of NTBs and (2) analyze the impact of eliminating regulatory barriers in the air transportation service within the scope of ASEAN and ASEAN FTA Partners. Using the gravity model, this study identifies that the trade barriers of air transportation services in ASEAN and ASEAN FTA Partners are still relatively high at between 0 - 11.2 percent. Using CGE's ICIRTS model, GTAP simulation shows that the results of this study are consistent with procompetitive theories. Greater gain is obtained from the CGE model, which uses the assumption of IC-IRTS compared to PC-CRTS. Assuming IC-IRTS, China will reap greater benefits as indicated by its highest increase in welfare.
\end{abstract}


Keywords: Air Transportation Services, Non-Tariff Barrier, IC-IRTS CGE Model, Gravity Model

JEL Classification: F13, F15, F17

\section{PENDAHULUAN}

Berbeda dengan sektor barang, hampir sebagian besar sektor jasa tidak dapat diraba (intangible) dan tidak terkena tarif. Sektor jasa tidak diproduksi dan disimpan untuk kemudian dikonsumsi, tetapi produksi dan konsumsi dilakukan secara simultan (Stern \& Hoekman, 1988). Konsekuensinya banyak hambatan di transaksi perdagangan sektor jasa berupa restriksi terhadap interaksi yang dilakukan produsen dan konsumen dibandingkan hambatan tarif yang umumnya terjadi pada perdagangan barang. Hambatan perdagangan di sektor jasa diterapkan oleh pemerintah melalui regulasi (Kalirajan, 2000).

Regulasi pada sektor jasa bertujuan untuk mengurangi asimetri informasi, namun regulasi yang tidak tepat bisa menjadi sarana yang sarat dengan keputusan politik (Rahardjo, 2004). Hal ini yang menyebabkan regulasi menjadi penghambat karena regulasi pada umumnya meningkatkan biaya transaksi yang pada akhirnya dibebankan ke konsumen dalam bentuk harga jasa yang lebih tinggi. Hertel et al.
(1999) dan Hertel (2000) menyatakan dalam salah satu model mereka bahwa efek dari regulasi yang berlebihan adalah peningkatan biaya yang sangat tinggi (cost escalating). Terkait dengan ekspor, Cusolito \& Hollweg (2015) menemukan bahwa berbagai kebijakan pemerintah menghambat diversifikasi pasar ekspor.

Liberalisasi perdagangan jasa di antara Negara ASEAN dilakukan melalui mekanisme yang diatur dalam ASEAN Framework Agreement on Services (AFAS). Untuk menindaklanjuti kesepakatan tersebut telah dibentuk Coordinating Committee on Services (CCS) yang memiliki tugas menyusun modalitas untuk mengelola negosiasi liberalisasi jasa dalam kerangka AFAS yang mencakup delapan sektor yaitu, jasa angkutan udara dan laut, jasa bisnis, jasa konstruksi, jasa telekomunikasi, jasa pariwisata, jasa keuangan, jasa kesehatan, dan jasa logistik. Konsekuensi dari liberalisasi adalah penurunan hambatan perdagangan yang dalam sektor jasa dalam bentuk regulasi. Studi Amala \& Heriqbaldi (2015) dengan 
menggunakan panel dinamis Indonesia saat ini kurang efektif karena menunjukkan bahwa keterbukaan di sektor jasa berpengaruh signifikan pada pertumbuhan ekonomi suatu negara. Li et al. (2007) menyatakan bahwa perdagangan internasional merupakan pintu masuknya teknologi ke suatu negara. Hasil penelitian menunjukkan bahwa impor jasa bisnis, transportasi dan pariwisata memiliki dampak positif bagi pertumbuhan ekonomi di negara maju. Penelitian di negara berkembang tidak dilakukan karena keterbatasan data. Penelitian Elkhoury \& Savvides (2006) sejalan dengan temuan Li et al. (2007). Hasil penelitian Elkhoury \& Savvides (2006); menemukan bahwa liberalisasi perdagangan jasa pada sektor telekomunikasi dan keuangan memberikan dampak positif dan signifikan pada pertumbuhan negara yang berpendapatan tinggi, sedangkan di negara berpendapatan rendah tidak memberikan dampak yang signifikan. Penelitian Mishra et al. (2011) juga menunjukkan adanya hubungan positif antara pertumbuhan ekonomi dan sektor jasa seperti halnya penelitian Whalley (2004) untuk kasus sektor perbankan, asuransi dan telekomunikasi. Namun demikian, beberapa pendapat menyatakan bahwa perjanjian perdagangan yang dimiliki perjanjian yang ada lebih menguntungkan mitra perdagangan yang mendapatkan akses terhadap pasar domestik. Bukti empiris menunjukkan bahwa defisit neraca perdagangan bilateral dapat terjadi setelah suatu negara memberlakukan FTA, seperti halnya dalam kasus Indonesia (ITAPS FEM IPB \& Kementerian Perdagangan, 2019).

Nilai perdagangan jasa menyumbang $25 \%$ dari nilai perdagangan ASEAN secara keseluruhan. Salah satu sektor jasa yang memiliki peran penting dalam perdagangan jasa adalah sektor jasa transportasi udara. Khusus untuk Indonesia, pertumbuhan penduduk dan peningkatan kesejahteraan ekonomi serta letak geografis yang unik dengan lebih dari 18.000 pulau tersebar di bentangan lebih dari $5.000 \mathrm{~km}$ menjadikan transportasi udara pilihan moda transportasi yang secara ekonomis paling murah. Dengan demikian, penerbangan merupakan sarana yang amat penting dan efisien dalam menghubungkan hampir 240 juta penduduk Indonesia, baik satu sama lain maupun dengan penduduk di belahan dunia lain. Pada tahun 2014, Indonesia berada di peringkat Sembilan 
terbesar sebagai pasar domestik, dan berada dalam 10 teratas sebagai angkutan kargo internasional.

Selain kondisi di atas, letak strategis Indonesia di jantung Asia Tenggara juga semakin menegaskan pentingnya pasar Indonesia dalam jasa penerbangan. Dengan kata lain, kondisi ini merupakan potensi bagi moda transportasi udara Indonesia. Penerapan ASEAN Open Skies pada tahun 2015 telah menyediakan akses tak terbatas bagi semua negara ASEAN. Dengan dibentuknya Roadmap for Integration of the Air Travel Sector (RIATS) pada tahun 2010, ASEAN mempersiapkan tahapan-tahapan perencanaan agar dapat diimplementasikan untuk mencapai open sky ASEAN Single Aviation Market (ASAM) tahun 2015 (Whittle, 2012). Salah satu kesepakatan yang dilakukan adalah pemberian kebebasan Kelima tanpa batasan untuk hak angkut penumpang di antara ibukota-ibukota di ASEAN, menghapus batasan-batasan yang dikenakan pada kebebasan Ketiga dan Keempat dan untuk meliberalisasi lebih jauh hak angkut kargo. Open sky akan memberikan dua keuntungan yaitu muncul dari perdagangan jasa dan dari pasar yang lebih kompetitif. Keuntungan dari perdagangan jasa diperoleh ketika maskapai-maskapai melayani rute-rute tertentu yang tepat sehingga memperoleh pangsa pasar atas ruterute tersebut. Hal ini berdampak pada penurunan biaya dan peningkatan kualitas. Sementara itu manfaat yang lebih kompetitif terjadi ketika persaingan ketat antara maskapai-maskapai inkumben yang tidak lagi dibatasi oleh peraturan mengenai pangsa pasar yang dapat dikuasai dan maskapai baru. Persaingan akan mendorong maskapaimaskapai untuk menurunkan harga jual tiket pesawat sehingga menguntungkan bagi konsumen. Oleh karena itu penting bagi Indonesia untuk mempersiapkan industri transportasi udara yang aman serta berbasis pada infrastruktur penerbangan yang memenuhi standar internasional (Marannu, 2010).

Tidak hanya di tingkat ASEAN, pada tahun 2012, pakta perdagangan bebas yang melibatkan ASEAN, China, Korea Selatan, Jepang, Australia, New Zealand dan India telah disepakati. Pakta perdagangan bebas yang disepakati pada hari terakhir Konferensi Tingkat Tinggi ke-21 ASEAN di Phnom Penh, 15-20 November 2012 disebut Kerja sama Ekonomi Regional Komprehensif (Regional Comprehensif Economic Partnership). Terkait dengan implementasi FTA ASEAN-China di 
bidang jasa, China telah mengajukan request kepada Indonesia untuk 10 sektor jasa termasuk didalamnya sektor jasa transportasi. Berkenaan dengan hal tersebut, telah disepakati bahwa basis offer untuk sektor-sektor yang masuk dalam Komitmen Pertama FTA ASEAN-China bidang Jasa adalah AFAS-4 diantaranya jasa transportasi udara yang selanjutnya telah masuk dalam AFAS-5. Sedangkan dengan Korea, ASEAN sepakat untuk menggunakan komitmen di lingkungan internal ASEAN (AFAS 4 Plus Minus) sebagai basis liberalisasi sektor jasa AKFTA. Sektor jasa transportasi masuk dalam AFAS 4 minus.

Sejalan dengan kerangka AFAS paket 2 , dalam rangka peningkatan kinerja perdagangan di sektor transportasi, khususnya transportasi udara pemerintah melakukan tinjauan terhadap seluruh peraturan dan kebijakan-kebijakan yang ada. Pertanyaannya bukan tentang ada atau tidaknya regulasi namun lebih pada jenis regulasi apa yang lebih tepat (appropriate) dan pada tingkat apa. Regulasi yang tepat (appropriate regulation) dapat meningkatkan kesejahteraan melalui realokasi sumberdaya untuk memperoleh hasil (outcomes) yang diinginkan masyarakat. Sebaliknya regulasi yang tidak tepat dapat mengurangi kesejahteraan ekonomi (economic welfare) secara neto.

Penelitian ini bertujuan untuk menjawab dua pertanyaan yaitu pertama, seberapa besar hambatan regulasi perdagangan sektor jasa transportasi udara ASEAN 5 dan Six ASEAN FTA Partners (China, Korea, Jepang, Australia, New Zealand dan India) dan kedua, bagaimana dampak ekonomi dari eliminasi hambatan regulasi perdagangan sektor jasa transportasi udara ASEAN 5 dan Six ASEAN FTA Partners. Besarnya hambatan regulasi yang merupakan Non-Tarif Barriers (NTBs) diestimasi dengan quantity based measures. Jager \& Lanjouw (1977) menyatakan argumentasinya bahwa quantity based measures cenderung lebih dipilih daripada price-based measures karena pengukuran tersebut lebih menjelaskan tentang efek dari NTBs dan berapa banyak NTBs mengurangi perdagangan. Pendekatan quantity based measures biasanya menggunakan gravity model. Beberapa studi yang menggunakan gravity model untuk mengestimasi ekuivalen tariff impor pada sektor jasa adalah Callaghan \& Uprasen (2008), Walsh 
(2006) dan Francois (1998). Studi Benz (2017) menggunakan STRI (Services Trade Restriction Index) sebagai proksi dari trade cost untuk mengestimasi ekuivalen tariff impor pada sektor jasa. Trade cost mengalami peningkatan karena adanya kebijakan pemerintah atau pun karena struktur geografi, sejarah, atau faktor selera.

Metode analisis untuk menjawab pertanyaan kedua adalah model Computable General Equilibrium (CGE) multi-region dan sektor. Penggunaan model CGE (model keseimbangan umum) dalam studi ini sejalan dengan pemikiran bahwa pada masa yang akan datang sektor jasa akan menuju pasar bebas sama dengan pasar barang. Oleh karena itu interaksi antara pelaku ekonomi menjadi kompleks dan sulit untuk dipahami dengan model keseimbangan parsial sehingga penggunaan CGE dianggap lebih tepat (Widyastutik et al., 2016).

Model keseimbangan umum juga diyakini lebih baik digunakan dalam menganalisis kondisi makroekonomi serta keterkaitan intersektoral dan keterkaitan antar sektor-sektor dan cocok digunakan untuk menganalisis isu-isu pada kebijakan perdagangan luar negeri (De Melo, 1988) dan Yeah et al. (1994). Penggunaan model
CGE Imperfect Competition-Increasing Return to Scale (IC-IRTS) dibanding model standar Perfect CompetitionConstant Renturn to Scale (PC-CRTS) pada penelitian ini diharapkan akan menangkap industri jasa transportasi yang memiliki karakteristik "network externalities" dan penuh dengan regulasi. Secara historis, industri jasa mempunyai karakteristik campuran dari "network externalities" (seperti telekomunikasi, keuangan, dan transportasi) dan sarat regulasi (seperti komunikasi, asuransi, jasa profesi) yang terjadi baik secara alami (karena skala ekonomi maupun menguasai input/ teknologi tertentu) maupun karena adanya kebijakan pemerintah yang merupakan hambatan untuk masuk pasar.

Karena adanya skala ekonomi/ penguasaan input/teknologi maupun adanya kebijakan pemerintah (berupa lisensi, paten, merk dagang) maka perusahaan dalam industri memiliki kekuatan pasar baik dalam bentuk oligopoli atau monopoli maupun oligopsoni atau monopsoni. Karena memiliki kekuatan pasar maka perusahaan akan memiliki kemampuan untuk mendorong terjadinya perbedaan harga antara perusahaan dan konsumen, antara penabung dan 
investor dan antara agen ekonomi (mark-up). Untuk itu dilakukan modifikasi dalam model Global Trade Analysis Project (GTAP) dengan mengubah asumsi Perfect CompetitionConstant Return to Scale (PC-CRTS) dengan Imperfect CompetitionIncreasing Return to Scale (IC-IRTS) yang mengacu pada studi Francois (1998). Penggunaan asumsi IC-IRTS dalam model GTAP pernah dilakukan oleh Panenungi (2004) pada kasus kawasan perdagangan bebas ASEANChina untuk mengakomodasi manfaat yang lebih besar yang terkadang tidak disadari sebagai akibat terjadinya perdagangan bebas dalam blok perdagangan atau multilateral.

Penelitian berkontribusi dalam melakukan kuantifikasi hambatan perdagangan di sektor jasa transportasi udara Indonesia dengan ASEAN 5 dan Six ASEAN FTA Partners mengakomodasi IC-IRTS dalam model GTAP, sesuai dengan karakteristik sektor jasa transportasi yang merupakan campuran dari "network externalities" dan sarat regulasi. Sejauh ini belum ada penelitian model keseimbangan umum yang mengakomodasi skala pengembalian yang meningkat dan pasar persaingan tidak sempurna (IC-IRTS) spesifik untuk sektor jasa transportasi laut dan udara di Indonesia dengan Negara ASEAN 4 serta mitra dagangnya. Studi terdahulu hanya sebatas mengestimasi hambatan di sektor jasa seperti studi Walsh (2006), Pham et al. (2014), Meidah (2016), Meidah dan Widyastutik (2016), Rofifah (2017), dan Ihsan (2019) dengan menggunakan gravity model dan beberapa untuk kasus di sektor barang seperti Sari \& Widyastutik (2015) dan Anggoro \& Widyastutik (2016).

Studi Callaghan \& Uprasen (2008) telah mengestimasi hambatan regulasi dengan model gravitasi dan menggunakan hasil ekuivalen tariff impor sebagai simulasi dalam model GTAP namun masih menggunakan model standar yaitu PC-CRTS. Studi Saptanto et al. (2017) mengestimasi hambatan non tarif dengan menggunakan price gap pada sektor perikanan dan menggunakan hasil estimasi sebagai simulasi dalam model GTAP standar. Studi Widyastutik et al. (2017) telah menggunakan model ICIRTS namun dalam kasus sektor jasa transportasi laut. Studi tentang sektor jasa berdasarkan moda juga telah dilakukan oleh Fawaiq (2014). 
METODE

\section{Estimasi Hambatan Regulasi \\ Perdagangan Sektor Transportasi \\ Udara ASEAN 5 dan Six ASEAN FTA \\ Partners \\ Konsep Model Gravity}

Model gravity dalam penelitian ini menggunakan model standar gravity
Anderson \& Van Wincoop (2001) (variabel ukuran pasar dan kapasitas perekonomian (GDP) dan jarak) dan ditambahkan beberapa variabel berdasarkan model gravity Rose (2002) (variabel Cont, Comlang_etno, Comlang_off dan dummy FTA). Berikut gravity model dalam paper ini.

$$
\begin{aligned}
& \ln X_{i j t}=\alpha+\beta_{1} \ln G D P_{i t}+\beta_{2} \ln G D P_{j t}+\beta_{3} \ln \text { Dist }_{i j}+\beta_{4} \text { Cont }_{i j}+\beta_{5} \text { Comlang_etno }_{i j} \\
& +\beta_{6} \text { Comlang_off }_{i j}+\beta_{7} \text { DummyFTA }_{i j t}+\varepsilon_{i j t}
\end{aligned}
$$

Dimana i dan j menunjukkan negara, $t$ menunjukkan waktu dan setiap variabel didefinisikan sebagai berikut:

$X_{i j t} \quad$ : Impor jasa transportasi (laut atau udara) negara j dari negara i pada tahun $\mathrm{t}$ (dalam USD)

$G D P_{i t}, G D P_{j t,} \quad$ : GDP masing-masing dari negara i dan j pada tahun $\mathrm{t}$ (dalam USD)

Dist $_{i j} \quad$ : Jarak geografi yang diperoleh dari CEPII

Cont $_{i j} \quad$ : Variabel dummy bernilai 1 jika i dan j berbagi perbatasan darat, dan sebaliknya 0 jika tidak berbagi perbatasan darat

Comlang_of $f_{i j} \quad$ : Variabel dummy bernilai 1 jika i dan j memiliki kesamaan bahasa resmi umum sedikitnya $20 \%$ dari populasi di kedua negara

Comlang_etno $_{i j}$ : Variabel dummy bernilai 1 jika i dan j memiliki bahasa yang dipergunakan sedikitnya 9\% dari populasi di kedua negara

DummyFTA $_{i j t} \quad$ : Variabel dummy bernilai 1 jika i dan j keduanya memiliki kesepakatan kerjasama perdagangan regional $\mathrm{k}$

$\begin{array}{ll}\alpha & : \text { Intersep } \\ \beta & : \text { Parameter } \\ & \text { diestimasi, } \mathrm{j}=1,2, \ldots \ldots \\ \varepsilon & : \text { error term }\end{array}$

Pada gravity model impor jasa transportasi udara, tingginya GDP negara importir mengindikasikan tingginya tingkat permintaan untuk jasa 
transportasi udara (yang diproduksi oleh domestik maupun impor), sedangkan tingginya GDP negara eksportir secara positif berhubungan dengan kemampuan untuk mengekspor lebih banyak jasa. Jarak yang digunakan adalah jarak geografi. Jarak antara negara eksportir dari importir memiliki dampak negatif pada perdagangan barang, namun berdasarkan review literatur terdahulu hasil empiris untuk kasus sektor jasa bersifat ambigu (Walsh, 2006; Callaghan \& Uprasen, 2008). Bahkan beberapa penelitian menunjukkan sektor jasa, karena karakteristiknya yang intangible, adalah relatif sedikit dipengaruhi oleh jarak daripada yang terjadi pada barang manufaktur maupun pertanian. Selain besarnya perekonomian (economic size) dan jarak beberapa faktor lain yang memengaruhi perdagangan adalah antara lain fenomena budaya (seperti whether the countries share a common languages), geografi yang sama (misalnya whether none, one or both are landlock), dan historical nature of the relationship between countries (e.g., whether one colonized the other), yang dapat dimasukkan ke dalam model (Rose, 2002).

Selain itu digunakan variabel dummy FTA untuk menangkap efek keanggotaan dalam FTA pada impor sektor jasa transportasi udara. Berdasarkan studi terdahulu Rose (2002) dan Walsh (2006), aplikasi gravity model untuk perdagangan barang memasukkan variabel ini untuk mengukur dampak dari FTA (Free Trade Area), tetapi untuk perdagangan jasa hal ini masih tidak jelas, karena sebagian besar perjanjian kerja sama berfokus pada perdagangan barang daripada perdagangan jasa. Untuk kasus ASEAN, walaupun integrasi ekonomi untuk kawasan ASEAN baru dimulai tahun 2015, namun negosiasi liberalisasi jasa (8 sektor jasa) telah dimulai sejak tahun 1995 termasuk sektor jasa transportasi.

Berdasarkan persamaan (1), untuk memperoleh equivalent tariff of NTBs diperlukan 2 kendala yaitu:

$\sum_{i} \varepsilon_{i j}=0$ dan

$\sum \mathrm{i} \sum_{j} \varepsilon_{i j}=0$

mengikuti Anderson \& Wincoop (2001), Park (2002), Callaghan \& Uprasen (2008). Residual $\varepsilon_{i j}$ didefinsikan sebagai log impor aktual dari eksportir i ke importer j dikurangi log dari impor potensial dari prediksi gravity model.

Sesudah semua parameter diestimasi, aliran perdagangan potensial dapat diperoleh dengan 
mensubtitusikan seluruh data ke dalam persamaan gravity yang diestimasi. The fitted trade flows dari persamaan gravity dispesifikasikan sebagai aliran perdagangan potensial. Berdasarkan pendekatan residual, perbedaan antara aliran perdagangan aktual dan potensial mengindikasikan tariff equivalent of

$t_{j}=\exp \left\{\ln \left(\frac{x_{j}^{a}}{x_{j}^{p}}\right)-\ln \left(\frac{x_{b}^{a}}{x_{b}^{p}}\right) \quad\right\}^{\frac{1}{\sigma}}=\frac{\left(x_{j}^{a} / x_{j}^{p}\right) \frac{1}{\sigma}}{\left(x_{b}^{a} / x_{b}^{p}\right)}$

$t_{j}$ adalah power of tariff equivalent dari NTBs. Tariff equivalent of NTBs importir $\mathrm{j},\left(t_{j}-1\right)$ diperoleh melalui persamaan (5) yaitu:

$\left(t_{j}-1\right)=\frac{\left(x_{j}^{a} / x_{j}^{p}\right)}{\left(x_{b}^{a} / x_{b}^{p}\right)}-1$

\section{Data dan Proses Estimasi}

Jenis data yang digunakan dalam gravity model adalah data sekunder berupa data panel. Data deret waktu yang digunakan adalah impor jasa transportasi udara dan GDP tahun 2001, tahun 2004, dan tahun 2007. Negara ASEAN yang dianalisis hanya Indonesia, Malaysia, Philipina, Thailand dan Singapura dengan pertimbangan 5 negara ASEAN tersebut mempunyai kontribusi sektor jasa terhadap GDP yang tertinggi (ASEAN Secretariat, 2012). Dengan demikian ASEAN $5+6$
NTBs yang dinormalisasi dengan freetrade benchmarks.

$\ln \left(\frac{x_{j}^{a}}{x_{j}^{p}}\right)-\ln \left(\frac{x_{b}^{a}}{x_{b}^{p}}\right)=-\sigma \ln t$

Dengan a, p, dan b adalah aktual, potensial dan benchmark. Berdasarkan persamaan (3) maka dapat dipecahkan $t_{j}$ yaitu:

negara mitra ASEAN dalam penelitian ini merupakan pakta perdagangan yang besar karena memiliki sepertiga dari PDB dunia dan 3,5 miliar jiwa.

Data impor jasa transportasi udara dan GDP bersumber dari GTAP version 6 tahun 2005 data dasar tahun 2001, version 7 tahun 2008 data dasar 2004, dan version 8 tahun 2012 data dasar tahun 2004 dan 2007. Penggunaan data impor jasa yang bersumber dari GTAP dilakukan oleh Sohn (2005); Lejour, Mooij, Nahuis (2001); Callaghan \& Uprasen (2008); Winchester (2008), Fontagne et al., (2011), Meidah \& Widyastutik (2016), Ihsan (2019). Sedangkan variabel jarak, continent, comlang_off (common languages off yaitu jika bahasa nasional digunakan oleh $20 \%$ populasi dari Negara tersebut), sedangkan comlang_etno 
(common languages etnic, yaitu jika satu bahasa digunakan sedikitnya $9 \%$ dari populasi) diperoleh dari CEPII's distance database.

Pengolahan regresi data panel menggunakan bantuan software Microsoft Office Excel dan Eviews dan karena dalam data panel terdapat variabel yang fixed konstan over time seperti jarak, lokasi, variabel dummy maka digunakan Random Effect Model (REM). Hal ini diperlukan karena REM mengasumsikan bahwa unobserved effect tidak berkorelasi dengan semua explanatory variables, baik explanatory variables fixed over time atau tidak (Woolridge, 2006). Variable yang konstan overtime dalam paper ini adalah jarak. Jarak antar suatu negara ke negara lain tidak akan berubah.

Metode Analisis Dampak Ekonomi Eliminasi Hambatan Regulasi Impor Sektor Jasa Transportasi Udara ASEAN 5 dan Six ASEAN FTA Partners

Model CGE: Imperfect Competition dan Skala Ekonomi yang Meningkat Global Trade Analysis Project (GTAP) merupakan Computable General Equilibrium (CGE) Model multi region dan multi sektor yang memiliki asumsi Perfect Competition-Constant Return to Scale (PC-CRTS). Dalam paper ini, asumsi PC-CRTS akan dirubah menjadi Imperfect CompetitionIncreasing Return to Scale (IC-IRTS) mengacu pada Francois (1996). Hasil dari pengembangan ini adalah penekanan tidak hanya pada efek realokasi tetapi juga efek prokompetitif. Gains from trade berhubungan langsung dengan skala ekonomi dan atau imperfect competition atau secara umum disebut efek pro kompetitif (pro competitive effect). Implikasi penggunaan asumsi IC-IRTS dalam model GTAP salah satunya untuk mengakomodasi gain yang lebih besar karena adanya perdagangan bebas (Francois, 1998; Pannenungi, 2004).

Untuk menangkap perilaku sektor jasa transportasi karena adanya intervensi pemerintah dilakukan modifikasi asumsi dalam model GTAP. Sebagai penyederhanaan, dalam mengukur elastisitas permintaan (DELAST), Francois (1998) menggunakan asumsi non-nested Armington dimana importcompeting goods bisa langsung bersaing dengan barang impor dari tiap negara secara langsung. Dalam IRTS, skala netto secara sederhana adalah SCALE $=C D R /(1-C D R)$. Data Cost Disadvantage Ratio (CDR) menggunakan data yang dipakai dalam Francois dan Roland-Holst (1997) 
sehingga perubahan skala output dengan mudah didapatkan dengan mengalikan SCALE dengan perubahan nilai tambah (value added) sektor yang bersangkutan. Dalam implementasi IC, persamaan mark up (mu) disesuaikan dengan GTAP sehingga didapatkan persamaan sebagai berikut:

$(1 /(1+\operatorname{SCALE}(\mathrm{i}, \mathrm{r}))) /(1-\operatorname{CVRATIO}(\mathrm{i}, \mathrm{r}) / \mathrm{DELAST}(\mathrm{i}, \mathrm{r}))$

Dimana i adalah firm dan $r$ adalah region. Berdasarkan persamaan diatas skala ekonomis secara langsung juga terkait dengan markup. Unsur utama markup terdapat pada Conjenctural Variation (CVRATIO) (i,r), yang merupakan conjenctural variation per number of firm-Conjenctural variation per $\mathrm{n}$ (firm number) memiliki nilai yang bervariasi yaitu berada pada nilai 0 hingga 1. Saat $\Omega=0$ menunjukkan perfect competition, ketika $\Omega=\mathrm{n}$ sama dengan perfectly collusive atau monopolistic market. Range yang ekstrim antara $1 \geq(\Omega / n) \geq 0$ menunjukkan tingkat kekuatan pasar, sedangkan dalam pendekatan ekonometrik organisasi industri nilai $\Omega / n$ menunjukkan ukuran umum relatif dari tingkat persaingan. Nilai CDR dan Conjectural Variation (CV) ratio mengacu pada studi Francois (1998), Francois \& Roland-Holst (1997), dan Elbehri \& Hertel (2006). DELAST tergantung pada market share (ZETA) dan Armington Domestic Demand Elasticity of Subtitution (CESUBD). Berdasarkan elastisitas Armington, jasa impor tidak disubtitusi secara sempurna oleh jasa asing. Konsumen akan mensubtitusi barang domestik dengan impor tergantung pada willingness to substitute dan rasio harga antara jasa domestik dan asing. Selanjutnya willingness to substitute dan rasio harga antara jasa domestik dan asing akan memengaruhi pangsa pasar dari perusahaan dalam industri atau dengan kata lain CESUBD memengaruhi ZETA. ZETA selanjutnya memengaruhi perilaku perusahaan dalam industri baik terkait harga maupun jumlah jasa yang akan disediakan di pasar.

Francois (1998) memperlakukan mark-up sebagai pajak yang memengaruhi harga dan kuantitas.

$$
\begin{aligned}
& \text { ps }(i, r)=\text { to }(i, r)+p m(i, r)-m u(i, r) \ldots \ldots \ldots .(7) \\
& p m(i, r)=p s(i, r)-\text { to }(i, r)+m u(i, r) \ldots \ldots \ldots .(8)
\end{aligned}
$$

Mekanisme harga diatas mark-up memengaruhi output dan variable 
lainnya. Perubahan dari CRTS ke IRTS dengan cara mengubah SCALE $=0$ menjadi SCALE $=\mathrm{CDR} /(1-\mathrm{CDR})$. Sedangkan perubahan dari Perfect Competition (PC) menjadi Imperfect Competition adalah mengubah CVRATIO dari 0 menjadi lebih besar dari 0 . Perubahan data dilakukan lewat GTAPDAT. HAR atau file Header Array yang digunakan untuk GEMPACK (General Equilibrium Modelling PACKage).

Salah satu bentuk intervensi pemerintah adalah terkait regulasi single majority dalam modal yang akan memengaruhi persaingan di jasa transportasi udara. Intervensi pemerintah tersebut akan memengaruhi struktur pasar dan perilaku perusahaan dalam industri. Perilaku oligopoli maupun monopoli tersebut ditangkap melalui persaingan yang tidak sempurna dan skala pengembalian yang meningkat (IC-IRTS). Dalam model GTAP, kondisi ini dicerminkan dalam CVRATIO yang mendekati nilai 1 .

\section{Simulasi}

Dalam penelitian ini, regulasi berlebihan diindikasikan sebagai tariff equivalent impor dari NTBs yang dalam GTAP tercermin dalam tarif impor (tms). Oleh karena itu simulasi yang diaplikasikan dalam GTAP adalah eliminasi hambatan biaya regulasi yang ekuivalen dengan eliminasi tarif

\section{Data dan Proses Estimasi}

Database GTAP yang digunakan adalah versi 8. Dalam penelitian ini pengurangan hambatan regulasi hanya pada sektor transportasi udara di lingkup ASEAN $5+6$ negara mitra ASEAN. Kontribusi lain dari penelitian ini adalah secara teknis melakukan penyesuaian pada model GTAP yang berasal dari versi 3 yang dipergunakan Francois (1998) untuk dapat diimplementasikan ke Model GTAP versi 8 (dengan agregasi negara dan sektor yang lebih banyak sesuai dengan keperluan penelitian) serta memperbarui tarif jasa sektor transportasi udara.

\section{HASIL DAN PEMBAHASAN}

Hasil Empiris Model Gravity dan Tariff equivalent of NTBs Impor Jasa Transportasi Udara ASEAN's Dialogue Partners

Hasil estimasi REM pada aliran impor bilateral dengan persamaan gravity model across country pada sektor jasa transportasi udara disajikan pada Tabel 1. Koefisien $R^{2}$ adalah sebesar $49 \%$ yang mengindikasikan hanya $49 \%$ dari variasi variabel dependent yang bisa dijelaskan oleh persamaan (model) ini. Hal ini 
menunjukkan banyak variable lain (ekonomi maupun non ekonomi) memengaruhi variabel dependent tapi tidak dimasukkan dalam persamaan/ model ini. Salah satu variabel non ekonomi yang berpengaruh dalam impor jasa adalah regulasi. Selain regulasi single majority dalam modal di jasa transportasi udara, regulasi terkait cabotage pada jasa transportasi udara menjadi kebijakan yang bersifat diskriminatif terhadap foreign supplier dan cenderung proteksi terhadap jasa pengangkutan domestik. Prinsip ini diindikasikan memengaruhi akses pasar sehingga penyediaan jasa transportasi udara oleh asing turun. Regulasi ini berpengaruh pada volume transaksi, jumlah operator, jumlah tenaga kerja dan kepemilikan modal asing yang selanjutnya akan memengaruhi jasa pelayanan ekspor dan impor baik barang maupun jasa lainnya.

Koefisien $R^{2}$ impor jasa transportasi udara pada penelitian ini lebih kecil dibandingkan dengan yang dihasilkan dalam Park (2002), Walsh (2006), dan Callaghan \& Uprasen (2008), Fontagne, Guillin, \& Mitaritonna (2011) dan Widyastutik et al. (2017).

Tabel 1. Model Gravitasi Impor Sektor Jasa Transportasi Udara

\begin{tabular}{lc}
\hline \multicolumn{1}{c}{ Independent Variable } & \\
\hline Konstanta & $-18,55$ \\
LnGDPi & $0,620^{\star * *}$ \\
& $(0,054)$ \\
LnGDPj & $0,765^{\star * *}$ \\
LnDist & $(0,055)$ \\
& $-0,196$ \\
Cont & $(0,165)$ \\
Comlang_Etno & $-0,321$ \\
& $(0,408)$ \\
Comlang_Off & 0,124 \\
& $(0,279)$ \\
DummyFTA & $-0,006$ \\
& $(0,319)$ \\
Observation & $-0,101$ \\
Country Pairs & $(0,242)$ \\
Adjusted R & 330 \\
$R^{2}$ & 110 \\
\hline
\end{tabular}

Keterangan: ***signifikan pada taraf nyata $1 \%$ Angka dalam kurung [ ] adalah standar error 
Berdasarkan hasil estimasi, pada taraf nyata 1\%, hanya variabel GDP importir dan eksportir yang berpengaruh signifikan terhadap impor sektor jasa transportasi udara, sedangkan variabel Distance, Cont, Comlang_etno tidak signifikan memengaruhi impor jasa transportasi udara. Hasil estimasi gravity model pada impor jasa transportasi udara menunjukkan bahwa peningkatan 1\% GDP Negara importir akan meningkatkan impor jasa transportasi udara sebesar 0,620\% (lebih rendah dibandingkan temuan Callaghan \& Urapsen, 2008 sebesar $0,55 \%$ ) ceteris paribus. Demand size yang ditunjukkan oleh besarnya GDP Negara importir mengindikasikan tingginya permintaan terhadap sektor jasa transportasi udara (baik yang diproduksi oleh domestik maupun impor), sejalan dengan temuan Walsh (2006); Callaghan \& Uprasen (2008); Fontagne, et al. (2009).

Hasil estimasi gravity model pada impor jasa transportasi udara menunjukkan peningkatan 1\% GDP Negara eksportir maka akan meningkatkan impor jasa transportasi udara sebesar $0.765 \%$ ceteris paribus. Mirza \& Nicoletti (2006) menyatakan bahwa penawaran sektor jasa ke pasar luar negeri berkaitan erat dengan ketersediaan input baik di pasar domestik maupun pasar luar negeri. GDP eksportir mendorong kapasitas untuk berproduksi yang selanjutnya akan meningkatkan ekspor jasa transportasi udara. Hal ini sesuai dengan karakteristik sektor jasa, bahwa produk jasa akan dihasilkan oleh Negara yang ukuran ekonominya (GDP) tinggi. Hayami \& Godo (2005) menyatakan bahwa Negara maju (advanced economies) aktivitas ekonominya akan bergeser dari sektor industri ke sektor jasa sebagai respon dari pertumbuhan ekonomi yang tinggi. Jarak tidak signifikan dalam memengaruhi impor jasa transportasi udara. Hasil ini tidak sejalan dengan temuan Anderson et al. (2014) yang menyatakan semakin jauh jarak maka biaya perdagangan akan semakin meningkat dan menurunkan ekspor dan impor. Namun hasil ini mendukung temuan Li et al. (2007). Hasil penelitian Li et al. (2007) menunjukkan kecepatan pertumbuhan pembangunan di sektor transportasi udara membuat jarak menjadi tidak berarti. Bahkan selanjutnya Li et al. (2007) menyebutnya sebagai "death of distance". Hasil penelitian Behar \& Venables (2010) bahwa kemajuan teknologi dalam transportasi telah 
mendorong peningkatan kualitas (kecepatan dan keandalan) transportasi sehingga biaya menjadi lebih rendah yang pada akhirnya merangsang perdagangan. Jarak tidak lagi signifikan memengaruhi pertimbangan pelaku ekonomi untuk melakukan kegiatan ekspor dan impor. Namun demikian mengingat sektor transportasi udara merupakan sektor jasa yang relatif secara fisik mengangkut barang dari lokasi satu ke lokasi lain, maka dalam model ini jarak memiliki hubungan negatif dengan impor jasa transportasi udara walaupun tidak signifikan secara statistik.

Selain variabel jarak yang tidak signifikan, variabel continent, comlang_off (common languages off yaitu jika bahasa nasional digunakan oleh $20 \%$ populasi dari Negara tersebut), comlang_etno (common languages etnis yaitu jika satu bahasa digunakan sedikitnya $9 \%$ dari populasi) tidak signifikan memengaruhi impor jasa transportasi udara. Perdagangan jasa transportasi udara lebih bersifat global (mendunia). Hal ini karena dalam jasa transportasi udara penggunaan bahasa internasional lebih relevan dibanding adanya kesamaan bahasa (yang diproksi dengan Comlang_etno maupun Comlang_off).
Tidak signifikannya dummy FTA menunjukkan liberalisasi sektor jasa transportasi udara belum sepenuhnya dilakukan baik di ASEAN maupun ASEAN's Dialogue Partners. Walaupun berdasarkan kesepakatan AFAS Negara Anggota ASEAN telah membuka perdagangan jasa transportasi sesuai persyaratan thresholds (tingkat keterbukaan arus jasa yang ditawarkan Indonesia adalah bebas untuk perdagangan jasa Mode 1 dan Mode 2, kepemilikan asing dibuka sebesar $51 \%$ untuk sebagian sektor prioritas, sedangkan untuk sektor non prioritas dibuka sampai $49 \%$ ) namun kesepakatan ini belum signifikan secara statistik memengaruhi perdagangan jasa transportasi udara. Salah satu penyebabnya adalah bervariasinya implementasi AFAS untuk setiap negara anggota ASEAN di sektor jasa transportasi udara.

Tan (2012) menunjukkan bahwa negara-negara anggota ASEAN memiliki perbedaan signifikan dalam komitmen mereka terhadap liberalisasi layanan perhubungan udara. ASEAN memiliki keragaman kapasitas dan prioritas di antara penerbangan negaranegara anggota. Di satu sisi, ada negara-negara seperti Singapura dan Brunei, yang tidak memiliki pasar 
domestik untuk dilindungi, dan hanya memiliki satu bandara internasional/ tujuan untuk ditawarkan. Implikasinya Singapura dan Brunei cenderung sangat liberal dalam menganjurkan akses pasar bebas, khususnya Singapura yang telah memiliki maskapai penerbangan nasional dan beberapa maskapai baru berbiaya rendah seperti Singapore Airlines (SIA). Di sisi lain, negara-negara seperti Indonesia, Filipina, dan Vietnam memiliki pasar domestik yang besar dan beberapa kota besar yang dapat dimanfaatkan untuk meningkatkan pengoperasian penerbangan internasional. Negaranegara ini cenderung lebih protektif pada pasar-pasar mereka. Selain perbedaan dalam hal kapasitas, para maskapai penerbangan ini pun memiliki pengaruh terhadap pemerintah mereka dalam tingkat yang berbeda-beda. Selain karena bervariasinya implementasi AFAS di ASEAN, untuk sektor jasa transportasi udara, implementasi secara nyata pelaksanaan perjanjian ASEAN Open
Skies baru diterapkan pada tahun 2015 . Implementasi Open Skies ASEAN diperkirakan akan menambah pertumbuhan permintaan jasa transportasi udara sebesar $6 \%$ hingga 10\% lagi (Prakarsa, 2012). Temuan ini sejalan dengan Grunfeld \& Moxnes (2003) yang menemukan bahwa keberadaan FTA tidak signifikan untuk sektor jasa. Grunfeld \& Moxnes (2003) juga memperkirakan bahwa FTA tidak mencakup perdagangan dalam sektor jasa.

Selanjutnya model prediksi dari persamaan impor jasa transportasi udara di atas digunakan untuk menghitung hambatan regulasi sebagai ekuivalen tarif impor. Elastisitas subtitusi mengacu pada penelitian terakhir Francois (2001) yang menggunakan elastisitas 1,26 untuk perdagangan sektor jasa. Free trade benchmark adalah impor Malaysia dari Indonesia. Tabel 2 ekuivalen tarif impor pada persamaan impor sektor jasa transportasi udara ASEAN 5 dan Six ASEAN FTA Partners. 
Tabel 2. Ekuivalen Tarif Impor Sektor Jasa Transportasi Udara ASEAN dan ASEAN's Dialogue Partners

\begin{tabular}{|c|c|c|c|c|c|c|c|c|c|c|c|}
\hline \multirow[b]{2}{*}{ Importir } & \multicolumn{11}{|c|}{ Eksportir } \\
\hline & Idn & Mys & Phl & Tha & Sgp & Chn & Jpg & Kor & Aus & $\mathrm{Nzl}$ & Ind \\
\hline Idn & - & 5.29 & 7.34 & 5.17 & 3.07 & 7.16 & 6.39 & 5.72 & 5.61 & 7.60 & 5.93 \\
\hline Mys & 0.00 & & 3.26 & 1.98 & 3.65 & 4.10 & 2.61 & 3.48 & 2.40 & 4.57 & 0.14 \\
\hline Phl & 3.62 & 4.52 & & 3.66 & 3.45 & 6.35 & 4.51 & 4.17 & 4.39 & 6.66 & 3.05 \\
\hline Tha & 1.26 & 4.67 & 5.28 & & 2.56 & 6.12 & 4.65 & 3.76 & 4.69 & 6.54 & 1.11 \\
\hline Sgp & 5.12 & 2.62 & 3.04 & 1.76 & - & 8.06 & 4.37 & 2.52 & 2.20 & 5.19 & 3.88 \\
\hline Chn & 4.96 & 7.44 & 9.07 & 6.62 & 10.60 & - & 6.11 & 5.45 & 8.36 & 10.32 & 4.87 \\
\hline Jpg & 6.17 & 6.06 & 6.03 & 4.10 & 2.47 & 6.34 & - & 3.71 & 7.04 & 7.71 & 2.76 \\
\hline Kor & 4.62 & 6.21 & 5.81 & 4.16 & 3.15 & 5.80 & 4.56 & - & 5.34 & 4.64 & 2.03 \\
\hline Aust & 3.67 & 6.90 & 8.03 & 6.22 & 0.04 & 6.96 & 8.02 & 5.29 & - & 9.95 & 1.64 \\
\hline $\mathrm{Nzl}$ & 7.16 & 6.67 & 8.02 & 6.62 & 5.11 & 8.07 & 7.21 & 6.60 & 7.81 & - & 5.59 \\
\hline Ind & 7.42 & 5.65 & 6.76 & 4.35 & 7.63 & 11.20 & 6.60 & 7.90 & 6.47 & 6.83 & - \\
\hline
\end{tabular}

Sumber: Hasil Estimasi

Rata-rata ekuivalen tarif impor di kawasan ASEAN. Peningkatan dalam jasa transportasi udara adalah 0 perdagangan jasa transportasi udara sampai dengan 11,2\%. Ekuivalen tarif impor jasa transportasi udara Malaysia dari Indonesia memiliki nilai yang paling rendah. Hal ini sebagai implikasi dari kerja sama bilateral antar anggota BIMEAGA (Brunei - Indonesia - Malaysia Philippines - East ASEAN Growth Association) untuk sektor penerbangan yang disepakati oleh Brunei Darussalam, Indonesia, Malaysia dan Filipina di Bandar Seri Begawan ditandatangani pada tanggal 21 Februari 1995. Selain kerja sama bilateral BIM-EAGA, disepakati Indonesia Malaysia Thailand Growth Triangle (IMT-GT) yang merupakan kerangka liberalisasi sektor angkutan udara menuju ASEAN Open Sky 2015. Sub region ini dapat dijadikan benchmark bagi growth triangles lainnya Malaysia-Indonesia merupakan respon kerja sama bilateral BIM-EAGA dan IMT-GT. Peningkatan perdagangan jasa transportasi udara tersebut merupakan konsekuensi rendahnya ekuivalen tarif impor jasa transportasi udara Malaysia dari Indonesia. Ekuivalen tarif impor jasa transportasi udara Malaysia dari Philipina, Malaysia dari Thailand, dan Thailand dari Indonesia, juga relatif rendah sebagai konsekuensi kerja sama bilateral BIMEAGA dan IMT-GT.

Ekuivalen tarif impor impor jasa transportasi udara untuk Indonesia ke negara ASEAN 5 dan Six ASEAN FTA Partners dalam penelitiannya ini lebih rendah dibandingkan dengan temuan Park (2002) untuk agregasi transportasi yaitu sebesar $22,52 \%$. Walaupun China 
telah melakukan kerja sama dengan ASEAN, namun ekuivalen tarif impor yang diaplikasikan China pada negara ASEAN masih relatif tinggi. Di antara negara ASEAN, ekuivalen tarif impor yang diaplikasikan China dari Indonesia adalah yang paling rendah yaitu sebesar 4,96\%, koefisien ini lebih rendah dibandingkan ekuivalen tarif impor Indonesia dari China yaitu sebesar $7,16 \%$.

\section{Eliminasi Hambatan Regulasi Sektor Jasa Transportasi Udara Dampak terhadap Kinerja Ekonomi Makro}

Berdasarkan Tabel 3, kesejahteraan sebagian besar negara, kecuali Philipina, Thailand, New Zealand dan India, yang terlibat dalam perdagangan, pada asumsi IC-IRTS adalah lebih tinggi dibandingkan pada asumsi PC-CRTS.

\section{Tabel 3. Dampak Eliminasi Hambatan Regulasi Sektor Jasa Transportasi Udara}

\section{Terhadap Indikator Makro}

\begin{tabular}{|c|c|c|c|c|c|c|c|c|}
\hline \multirow[b]{2}{*}{ Negara } & \multicolumn{2}{|c|}{$\begin{array}{c}\text { Kesejahteraan } \\
\text { (Juta USD) }\end{array}$} & \multicolumn{2}{|c|}{$\begin{array}{l}\text { GDP Riil } \\
(\%)\end{array}$} & \multicolumn{2}{|c|}{$\begin{array}{c}\text { Neraca Perdagangan } \\
\text { (Juta USD) }\end{array}$} & \multicolumn{2}{|c|}{$\begin{array}{c}\text { Dasar Tukar } \\
\text { Perdagangan (\%) }\end{array}$} \\
\hline & IC-IRTS & PC-CRTS & IC-IRTS & PC-CRTS & IC-IRTS & PC-CRTS & IC-IRTS & PC-CRTS \\
\hline Idn & 45.04503 & 2.172084 & 0.01191 & 0.00037 & -3.03198 & -3.26995 & -0.00769 & 0.000336 \\
\hline Mys & 20.92648 & -3.448004 & 0.00396 & -0.00969 & 1.62490 & -0.40170 & 0.00327 & 0.009010 \\
\hline Phl & 4.851535 & 7.051462 & 0.00249 & 0.00146 & 0.30241 & -2.36160 & 0.00163 & 0.007366 \\
\hline Tha & 1.484456 & 24.25733 & 0.00198 & 0.00239 & -2.48595 & -0.98251 & -0.00233 & 0.011875 \\
\hline Sgp & 3.663463 & 3.516114 & 0.00064 & 0.00088 & 1.29105 & -9.62759 & 0.00089 & 0.001949 \\
\hline Chn & 803.3112 & 21.716265 & 0.02761 & 0.00036 & 93.53555 & -21.27658 & -0.01724 & 0.000312 \\
\hline Jpn & 122.1849 & 43.913128 & 0.00157 & 0.00036 & -36.16458 & -23.77539 & 0.00577 & 0.003711 \\
\hline Kor & 43.09654 & 4.81444 & 0.00359 & 0.00047 & -8.74705 & -22.44743 & 0.00090 & -0.000002 \\
\hline Aus & 76.6794 & 36.856976 & 0.00875 & 0.00154 & -4.36382 & -34.29565 & 0.00316 & 0.013072 \\
\hline $\mathrm{Nzl}$ & 2.649637 & 8.568974 & 0.00129 & 0.00216 & -2.00803 & -5.39053 & 0.00236 & 0.016303 \\
\hline Ind & -7.85986 & -0.244682 & 0.00024 & 0.00041 & -39.95226 & -9.06093 & -0.00346 & -0.002328 \\
\hline ROW & 455.1908 & -203.197495 & 0.00052 & -0.00023 & 0.00000 & 132.88983 & 0.00147 & -0.001002 \\
\hline
\end{tabular}

Sumber: Hasil Simulasi

Dengan asumsi IC-IRTS, dan Six ASEAN FTA mitra lainnya, reformasi regulasi di sektor jasa transportasi udara memberikan keuntungan berupa peningkatan kesejahteraan bagi China lebih tinggi dibandingkan dengan negara ASEAN 5 sesuai dengan Li et al. (2007). Industri penerbangan China mencapai kesuksesan setelah melakukan reformasi industri tahun 1987 dan 2002 , dari semula dikontrol oleh pemerintah 
menjadi liberalisasi pasar. Kondisi ini didukung oleh penelitian Li et.al (2007). Industri jasa transportasi China mengalami pertumbuhan yang cepat sejak tahun 1990-an. Jumlah rute penerbangan meningkat dari 287 pada tahun 1986 menjadi 1,257 pada tahun 2005, meningkat 34 kalinya. Realisasi turnover total pada tahun 2009 adalah 41.2 miliar ton kilometer, rangking kedua di dunia. Strategi yang digunakan adalah melakukan akselerasi pembangunan infrastruktur transportasi udara diantaranya pembangunan hub bandara Beijing, Shanghai dan Guangzhou. China merencanakan pembangunan 70 bandara baru pada periode 2011-2015. Untuk mencapai tujuan, China juga melakukan merger dan akuisisi antara China Eastern dan Shanghai Airlines.

Selain China, peningkatan kesejahteraan tertinggi terjadi di Indonesia. Hal ini sesuai dengan prediksi IATA (2015) bahwa China dan Indonesia merupakan negara yang diprediksi memiliki pasar paling tinggi dalam penambahan penumpang angkutan udara. Untuk kasus Indonesia, berdasarkan PDB per kapita permintaan domestik Indonesia terhadap transportasi udara untuk penerbangan domestik dan luar negeri lebih besar dari yang diperkirakan (Gambar 1).

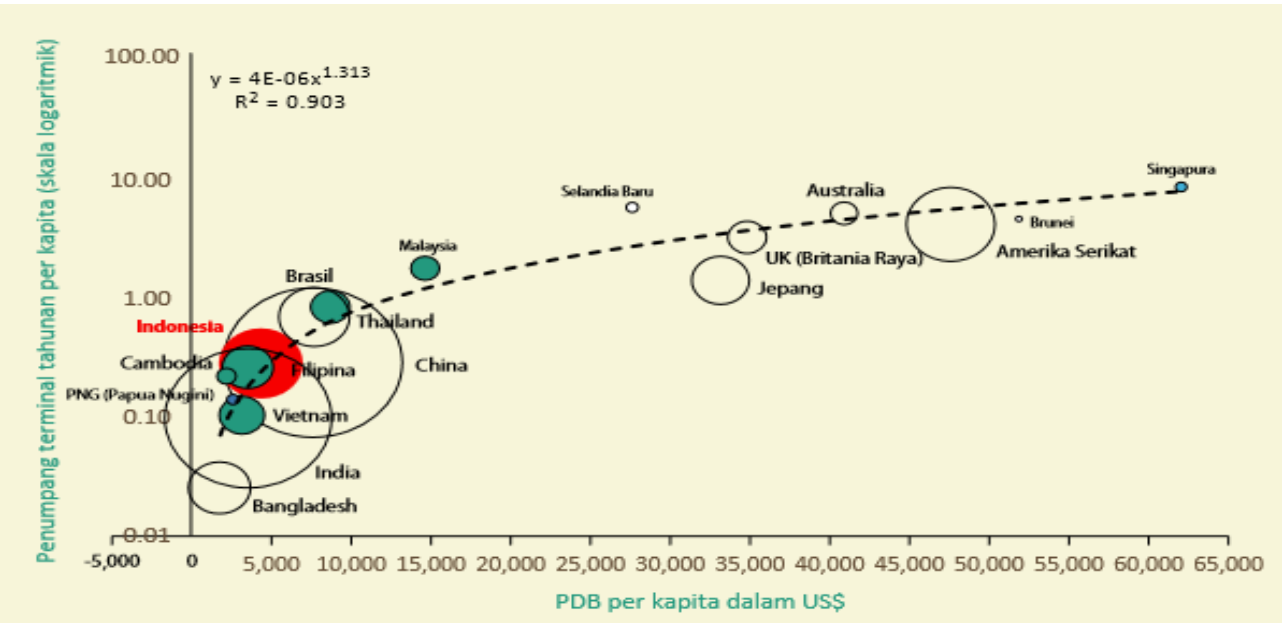

\section{Gambar 1. Kecenderungan untuk Terbang Sebagai Fungsi dari PDB per Kapita}

Sumber: Bank Dunia, Intelijen Transportasi Udara, CIA Factbook dan analisis (Helios dalam_Fairbanks, 2012)

Sektor jasa transportasi udara menciptakan "lingkaran kebajikan" (virtuous circle) dalam pertumbuhan ekonomi yang diikuti oleh peningkatan permintaan sehingga menciptakan pertumbuhan lebih besar. Hal ini relevan 
bagi Indonesia, mengingat Indonesia tempat industri minyak dan ekstraksi (keduanya sangat mengandalkan transportasi udara dibandingkan industri lainnya) yang menjadi penyumbang signifikan bagi pertumbuhan ekonomi. Konsekuensinya perlu peningkatan (upgrading) pada infrastruktur bandara dan infrastruktur pengendalian lalu lintas udara bandara di Indonesia untuk dapat memenuhi permintaan yang diproyeksikan meningkat, serta sistem kelembagaan dan peraturan dikembangkan sejalan dengan infrastruktur. Dari sisi permintaan luar negeri, kesepakatan Open Skies mengindikasikan bahwa penerapan kebijakan Open Skies ASEAN dapat menambah permintaan sebesar 6 hingga $10 \%$. Oleh karena itu, setelah implementasi Open Skies, pertumbuhan dalam permintaan perjalanan udara internasional di Indonesia, dapat bertumbuh hingga mencapai $20 \%$ per tahun. Selain Indonesia, negara ASEAN lainnya seperti Malaysia dan Philipina memiliki kecenderungan untuk terbang yang lebih tinggi dari yang diperkirakan dibandingkan Singapura (Fairbank, 2012).

Dengan asumsi IC-IRTS diperoleh sensitive gain yang lebih besar berupa peningkatan GDP riil dibandingkan dengan asumsi PC-CRTS. China mengalami peningkatan GDP riil tertinggi, disusul Indonesia. Asumsi ICIRTS mendorong monopolis untuk mengarah pada harga yang kompetitif sehingga output mengalami ekspansi lebih tinggi dibandingkan asumsi PCCRTS. Dengan asumsi IC-IRTS, insentif peningkatan output tidak hanya terjadi di sektor jasa transportasi udara namun juga di sektor lain yaitu wearing apparel, utility_contruction, other transport, dan trade. Sedangkan dengan asumsi PCCRTS, peningkatan output selain di sektor jasa transportasi udara juga terjadi di sektor heavy_manufacture, utility_construction, other transport, communication, trade, finance, insurance and business, dan tourism.

Seperti halnya pada sektor jasa transportasi udara, eliminasi hambatan regulasi pada sektor jasa transportasi udara ASEAN 5 dan Six ASEAN FTA Partners menyebabkan neraca perdagangan Indonesia bernilai negatif. Kekuatan penawaran ekspor Indonesia belum mampu merespon peluang eliminasi hambatan perdagangan. Kebijakan eliminasi dalam hambatan perdagangan lebih berpotensi meningkatkan laju pertumbuhan impor daripada ekspor. Respon peningkatan penawaran yang diikuti peningkatan 
ekspor hanya terjadi pada sektor jasa transportasi udara sendiri serta tekstil (wearing apparel). Hal ini menunjukkan sektor transportasi udara belum mampu menjadi "knock on effect" dalam perekonomian. Namun dengan asumsi IC-IRTS, sektor transportasi udara mampu menjadi "knock on effect" dalam perekonomian salah satunya pada sektor pariwisata (tourism).

Untuk China, the World Tourism Organisation memperkirakan bahwa China akan menjadi "the world's largest inbound travel country" dan "fourth largest for outbound tourists" pada tahun 2015. Sektor transportasi udara China mampu menjadi knock on effect sektor perekonomian lainnya diantaranya sektor pariwisata. Bahkan dengan Indonesia, terdapat rute langsung Guangzhou-Jakarta oleh Garuda Indonesia yang dilayani secara reguler.

Dengan asumsi IC-IRTS, Indonesia, Thailand, India bahkan China memiliki TOT yang menurun. Efek skala dan pasar persaingan ketika terjadi liberalisasi perdagangan menimbulkan konsekuensi ancaman impor karena masuknya penyedia asing. Kondisi ini mendorong monopolis untuk mengarah pada harga yang kompetitif. Efek prokompetitive berhubungan dengan skala ekonomi yang meningkat dan biaya yang turun menekan harga mengalami penurunan. Hal ini menjelaskan hargaharga ekspor secara relatif mengalami penurunan terhadap harga impor pada kondisi IC-IRTS. Penurunan term of trade terbesar terjadi di China. Hal ini menunjukkan efek pro-kompetitif yang berhubungan dengan skala ekonomi yang meningkat dan biaya yang turun di China lebih besar dibandingkan di negara lainnya.

\section{Dampak terhadap Kinerja Ekonomi Sektoral}

Pada asumsi IC-IRTS, eliminasi hambatan regulasi di sektor jasa transportasi udara menyebabkan sektor air transport, textile and wearing apparel, trade, other transport dan util_const mengalami peningkatan output dibandingkan dengan pada asumsi PC-CRTS. Nilai CDR yang digunakan untuk industri tekstil mengacu pada penelitian Elbehri \& Hertel (2006) dimana untuk Indonesia dan China memiliki nilai 0,24 dimana nilai ini lebih tinggi dibandingkan dengan negara lain. Nilai CDR yang lebih besar yang memengaruhi skala pengembalian hasil di sektor textile and wearing apparel Indonesia dan China ketika terjadi simulasi eliminasi hambatan regulasi di sektor jasa transportasi 
udara. Peningkatan output textile and wearing apparel di Indonesia dan China menduduki posisi tertinggi dibandingkan dengan sektor lainnya, bahkan bila dibandingkan dengan output air transport sendiri. Peningkatan output di sektor air transport tertinggi terjadi di Indonesia, disusul Malaysia dan Singapura. Permintaan terhadap jasa penerbangan sudah terlihat sebelum penerapan kebijakan Open Skies ASEAN. Kerja sama bilateral antar anggota BIM-EAGA (Brunei - Indonesia - Malaysia - Philippines - East ASEAN Growth Association) untuk sektor penerbangan sejak tanggal 21 Februari 1995 dan kerja sama bilateral Indonesia, Malaysia, Thailand Growth Triangle (IMT-GT) yang merupakan kerangka liberalisasi sektor angkutan udara menuju ASEAN Open Sky 2015

mendorong peningkatan output lebih besar di Indonesia, Malaysia, dan Singapura.

Namun demikian untuk kasus Indonesia, dengan asumsi IC-IRTS terdapat beberapa sektor di Indonesia yang mengalami kontraksi, namun mengalami ekspansi jika menggunakan asumsi PC-CRTS. Sektor-sektor tersebut adalah heavymnf, communicat, fininbis, dan tourism.
Sedangkan untuk kasus Malaysia, eliminasi hambatan regulasi di sektor jasa transportasi udara dengan asumsi IC-IRTS meningkatkan output Malaysia di hampir seluruh sektor kecuali textwapp, util_cons, fininbis, dan tourism. Kondisi ini menunjukkan sektor transportasi udara Malaysia telah sepenuhnya menjadi knock on effect dalam perekonomian dibandingkan dengan Indonesia. Secara teori, eliminasi ekuivalen tarif impor akan memberikan insentif bagi produsen untuk meningkatkan output dan menurunkan harga agar dapat bersaing dengan produk impor atau dapat meningkatkan output untuk ekspor. Ekspansi output mendorong peningkatan ekspor dan permintaan tenaga kerja. Rekruitmen terhadap tenaga kerja baik yang terdidik maupun tidak terdidik akan meningkat. Untuk kasus Indonesia, dengan asumsi ICIRTS sektor yang mengalami peningkatan ekspor dan permintaan tenaga kerja adalah sektor textile and wearing apparel dan air transport. Namun demikian terdapat beberapa sektor yang outputnya mengalami peningkatan namun ekspornya mengalami penurunan. Sektor-sektor tersebut adalah util_const; trade; dan othertransp. Peningkatan output kurang 
dari $1 \%$, terlalu kecil untuk mendorong peningkatan ekspor.

\section{KESIMPULAN DAN REKOMENDASI KEBIJAKAN}

Dengan pendekatan residual gravity model, rata-rata ekuivalen tarif impor dalam jasa transportasi udara adalah 0 sampai dengan 11,2\%. Ekuivalen tarif impor jasa transportasi udara Malaysia dari Indonesia memiliki nilai yang paling rendah. Hal ini sebagai implikasi dari kerja sama bilateral antar anggota BIM-EAGA (Brunei - Indonesia - Malaysia - Philippines - East ASEAN Growth Association) dan kerja sama bilateral BIM-EAGA, disepakati Indonesia Malaysia Thailand Growth Triangle (IMT-GT) yang merupakan kerangka liberalisasi sektor angkutan udara menuju ASEAN Open Sky 2015. Walaupun China telah melakukan kerja sama dengan ASEAN, namun ekuivalen tarif impor yang diaplikasikan China pada negara ASEAN masih relatif tinggi. Di antara negara ASEAN, ekuivalen tarif impor yang diaplikasikan China dari Indonesia adalah yang paling rendah yaitu sebesar 4,96\%, koefisien ini lebih rendah dibandingkan ekuivalen tarif impor Indonesia dari China yaitu sebesar $7,16 \%$.

Sejalan dengan teori efek prokompetitif dari kebijakan perdagangan, eliminasi hambatan regulasi pada sektor jasa transportasi udara pada penelitian ini menunjukkan gain from trade yang lebih besar diperoleh dalam model CGE dengan asumsi IC-IRTS dibandingkan dengan PC-CRTS kecuali Thailand, Filipina, New Zealand dan India. Surplus neraca perdagangan terjadi di Malaysia, Singapura, dan Filipina sebagai dampak eliminasi hambatan regulasi di sektor jasa transportasi udara. Sedangkan Indonesia, Thailand serta negara lainnya mengalami defisit. Dampak eliminasi hambatan regulasi perdagangan sektor jasa transportasi udara memberikan insentif peningkatan output pada sektor transportasi udara (air transport); tekstil dan produk tekstil (textile and wearing appare), perdagangan (trade), utility construction; sektor transportasi lainnya (othertransp). Hal ini menunjukkan sektor jasa transportasi udara Indonesia belum mampu menjadi "knock on effect" dalam perekonomian. Untuk kasus Indonesia, dengan asumsi IC-IRTS sektor yang mengalami peningkatan ekspor dan permintaan tenaga kerja adalah sektor textile and wearing apparel dan air transport.

Hasil estimasi tarif ekuivalen dari NTBs menunjukkan masih tingginya hambatan regulasi di sektor transportasi 
udara ASEAN dan ASEAN mitra FTA ASEAN memiliki keragaman kapasitas dan prioritas untuk masing-masing sektor jasa. Untuk memenuhi kesepakatan dalam AEC Blueprint, beberapa Negara anggota ASEAN masih harus berusaha keras untuk mencapai target yang sudah disepakati. Di satu sisi, anggota ASEAN seperti Singapura sangat liberal dan menganjurkan akses pasar bebas. Di sisi lain, negara-negara seperti Indonesia, Filipina, dan Thailand memiliki pasar domestik yang besar yang cenderung diproteksi. Kesuksesan reformasi regulasi di sektor jasa transportasi udara ASEAN dan ASEAN mitra FTA tergantung dari political will dari pemerintah masing-masing negara untuk memenuhi kesepakatan AEC Blueprint. Rekomendasi kebijakan kedua adalah meningkatkan fasilitasi perdagangan ASEAN dan ASEAN mitra FTA. Fasilitasi perdagangan antar Negara anggota ASEAN dan ASEAN mitra FTA diperlukan untuk mengatasi eksternalitas regulasi (perbedaan regulasi) yang akan mengurangi gain from trade seperti adanya oligopoli internasional di perdagangan jasa transportasi udara. Studi Pellan \& Wong (2010) juga membuktikan wilayah ASEAN terfragmentasi sehingga menyebabkan inefisiensi administrasi perbatasan. Dampak selanjutnya adalah terjadi peningkatan biaya dan waktu penerbangan sehingga memengaruhi daya saing ekspor barang dan jasa negara anggota ASEAN. Upaya riil yang dapat dilakukan adalah anggota ASEAN dan ASEAN's Dialogue Partners sebagai bentuk fasilitasi perdagangan adalah menciptakan custom environment dengan lebih meningkatkan fungsi Electronic Data Interchange (EDI) yang selama ini sudah berlaku. Implementasi fungsi EDI akan membantu pelayanan jasa dokumen ekspor impor yaitu jasa Pemberitahuan Impor Barang (PIB) dan Pemberitahuan Ekspor Barang (PEB) via jasa transportasi udara.

Hasil simulasi yang dilakukan pada studi ini juga menunjukkan bahwa meskipun terdapat potensi dampak positif dari kerja sama eliminasi hambatan regulasi, Pemerintah Indonesia harus mewaspadai adanya potensi tekanan negatif terhadap beberapa sektor. Pendekatan GTAP yang digunakan pada penelitian ini telah mengidentifikasi sektor yang memiliki potensi mengalami dampak negatif diantaranya yaitu agriculture, mining, light manufacturing, processing food, and sea transport. Sektor yang 
mengalami peningkatan output adalah air transport, textile and wearing apparel, trade, other transport dan util_const. Informasi ini akan sangat bermanfaat bagi pemerintah dalam merumuskan beberapa kebijakan pendamping yang perlu dilakukan untuk meminimalisir kemungkinan dampak negatif terhadap sektor-sektor yang teridentifikasi sebagai sektor loser. Bentuk spesifik dari asistensi, bantuan teknis maupun insentif lain yang diberikan tentu akan tergantung kepada kebutuhan pelaku usaha dan perlu dilakukan idenfikasi lebih lanjut.

\section{UCAPAN TERIMA KASIH}

Ucapan terima kasih disampaikan kepada Promotor S3 Penulis, Prof. Dr. Suahasil Nazara, Prof. Dr. Rina Oktaviani (alm), Dr. Djamester Simarmata dan Dosen Penguji, Dr. Madarremeng Pannenungi yang memberikan arahan ketika diskusi dengan penulis.

\section{DAFTAR PUSTAKA}

Amala, F., Heriqbaldi, U. (2015). Dampak Keterbukaan Perdagangan Sektor Jasa Terhadap Pertumbuhan Ekonomi: Pendekatan Panel Dinamis. Jurnal Ekonomi dan Bisnis, No. 2. 114-124.

Anderson, J., E. \& Van Wincoop, E. (2001). Gravity with Gravitas: A Solution to the Border Puzzle. NBER Working Paper, No.8079.
Anderson, J.E, Millot C. A, Yotov Y. (2014). How Much Does Geography Deflect Services Trade? Canadian Answers. International Economics Review 55 791-818.

Anggoro \& Widyastutik. (2016). Non-Tariff Barrier and factors that Influence the Indonesian Cocoa Export to Europa. Signifikan: Jurnal IImu Ekonomi. Vol 5(2) October 2016.

Behar \& Venables. (2010). Transport Cost and International Trade. Economics Series Working Paper 488. Oxford: University of Oxford Department of Economics.

Benz, S. (2017). Services Trade Cost: Tariff Equivalents of Services Trade Restrictions Using Gravity Estimation. OECD Trade Policy Papers. Paris: OECD Publishing.

Callaghan, B., A. \& Uprasen, U. (2008). Impact of the Fifth EU Enlargement on ASEAN. Ireland: Euro-Asia Centre (EAC), Departement of Economics Kemmy Business School University of Limerick.

Cusolito A.P, Hollweg C.H. (2015). Trade Policy Barriers: An Obstacle to Export Diversification in Eurasia. Journal of Banking and Financial Economics 2:91-129.

De Melo, J. (1988). CGE Models for The Analysis of Trade Policy in Developing Countries. Policy Research Working Paper Series 3, The World Bank.

Elbehri dan Hertel. (2006). A Comparative Analysis of The EU-Morocco vs Multilateral Liberalization. Journal of Economic Integration Vol. 21 496525.

Elkhoury, Antoine C., \& Andreas Savvides. (2006). Openness in Services Trafe and Economic Growth. Economic Letters 92, pp. 277-283.

Fairbanks, M. (2012). Lalu Lintas Bertumbuh, Kebutuhan Bertumbuh. 
Jurnal Prakarsa Infrastruktur Indonesia. Edisi 9 Januari 2012.

Fawaiq, M. (2014). Peluang Ekspor Jasa Indonesia ke Jepang Melalui Mode 3 (Commercial Presence) dan Model 4 (Movement of Natural Persons) pada Kerjasama IJEPA. Buletin IImiah Litbang Perdagangan. 8(1): 25-50.

Fontagne, L., Guillin A., \& Mitaritonna, C. (2009). Assessment of Tariff Equivalents for Services Considering Zero Trade Flows. CEPII No 201124 December

Fontagné, Lionel, Amélie Guillin, \& Cristina Mitaritonna. (2011). Estimations of Tariff Equivalents for the Services Sector. CEPII Working Paper No. 2011-24. Paris: Centre d'Etudes Prospectives et d'Informations Internationales.

Francois, J., F. (1998). Scale Economies and Imperfect Competition in the GTAP Model. GTAP Technical Paper No. 14.

Francois, J.F. \& D. Roland-Holst. (1997). Scale Economies and Imperfect Competition. In J.F. Francois and K.A. Reinert. Eds. Applied Methods for Trade Policy Analysis: A Handbook. New York: Cambridge University Press.

Francois, J. (2001). The Next WTO Round: North-South Stakes in New Market Acces Negotiations. Adelaide: Centre for International Economic Studies.

Grunfeld, L.A. \& A. Moxnes. (2003). The Intangible Globalization: Explaining the Patterns of International Trade in Services. Discussion Paper, 657.

Hayami, Y \& Godo, Y. (2005). Development Economics. From the Poverty to The Wealth of Nations. Third Edition. New York: Oxford University Press.

Hertel, T.W. (2000). GTAP Tutorial. Website: www.gtap.org.

Hertel, T., Anderson, K., Francois, J. \& Martin, W. (1999). Agriculture and Non-Agricultural Liberalisation in the
Millenium Round. Paper presented at the Global Conference on Agriculture and the New Trade Agenda from a Development Perspective: Interests and Options in the WTO 2000 Negotiations. Geneva: World Bank and WTO.

IATA. (2015). Annual Review IATA. $71^{\text {st }}$ Annual General Meeting. Miami: IATA.

Ihsan, M. (2019). Ekuvalen Tarif dan Determinan Impor Jasa Transportasi Udara Negara Anggota ASEAN dengan Taiwan. Skripsi. Bogor: IPB.

ITAPS dan Kementerian Perdagangan. (2019). Review Hasil Perundingan Kerjasama Perdagangan Internasional. Laporan Penelitian. Tidak Dipublikasikan. Jakarta: ITAPS Kemendag.

Jager, H. and Lanjouw, G. (1977). An Alternative Method for Quantifying International Trade Barriers. Review of World Economics. Vol.113, issues 4, pages 719-740.

Kalirajan, K. (2000). Restrictions on Trade in Distribution Services. Productivity Comissions Staff Research Paper. Canberra: Ausinfo.

Lejour, A.M., de Mooij, R.A. Nahuis, R. (2001). EU: Enlargement: Economic Implication for Countries and Industries. CPB Document 11. $C P B$ Netherland Bureau for Economic Policy Analysis.

Li, K., Song, L., \& Zao, X. (2007). Component Trade and China's Global Economic Integration in Garnauts and Song (Eds), China Linking Markets for Growth. Canberra: ANU E Press.

Marannu, M.N. (2010). Singapura dan Kerjasama Open Sky di ASEAN. Jakarta: Universitas Indonesia.

Meidah. (2016). Ekuivalen Tarif dan Determinan Impor Jasa Finansial dan Asuransi Negara RCEP. Skripsi. Bogor: IPB. 
Meidah \& Widyastutik. (2016). Determinan dan Ekuivalen Tarif Impor Jasa Finansial dan Asuransi negara RCEP. Buletin IImiah Litbang Perdagangan. Vol. 10, No. 2, Desember 2016.

Mirza, D \& Nicoletti, G. (2006). What is So Special About Trade in Services. Research Paper 2004,2, diunduh pada tanggal 5 November 2015. https://www.researchgate.net/publica tion/228238672 What is So Specia About Trade in Services.

Mishra, S., Susanna L., Rahul A. (2011). Services Export Shopistication and Economic Growth. Policy Research Working Paper 5606. Washington D.C.: The World Bank South Asia Region Economic Policy and Poverty.

Pannenungi, M., A. (2004). Model CGE dengan Skala Ekonomi yang Meningkat dan Persaingan Tidak Sempurna: Aplikasi pada Studi Kawasan Perdagangan ASEANChina. Disertasi. Depok: FE UI.

Park, S., C. (2002). Measuring Tariff Equivalent in Cross Border Trade in Services. KIEP Working Paper 02-15, Korea Institute for International Economic Policy.

Pellan, M.I., \& Wong M., H. (2010). Trade Facilitation in ASEAN+6 Economies: Provisions in FTAs, Performance and The Way Forward in ASEAN and Regional Free Trade Agreements Edited by Christopher Findlay. Routledge-ERIA Studies in Development Economics.

Pham VN, N T Dao, \& Q H Doan. (2014). Analyzing the Determinants of Services Trade Flows Between Vietnam adn European Union: $A$ Gravity Model Approach. Hanoi (VN): Hanoi National University.

Prakarsa. (2012). Infrastruktur Penerbangan: Tinjauan ke Masa Depan. Jurnal Prakasa Infrastruktur Indonesia. Edisi 9, Januari 2012.

Rahardjo, S. (2004). Ilmu Hukum: Pencarian, Pembebasan, dan
Pencerahan. Surakarta: Universitas Muhammadiyah.

Rofifah, N. (2017). Ekuivalen Tarif dan Determinan Impor Jasa Telekomunikasi Negara APEC. Skripsi. Bogor: IPB.

Rose, A., K. (2002). Estimating Protectionism through Residuals from the Gravity Model. Berkeley: University of California.

Saptanto, S., Rahadian, R., Tajerin. (2017). Dampak Hambatan Non Tarif Terhadap Kinerja Makroekonomi dari Sektor Perikanan dengan Menggunakan Model GTAP. Jurnal Sosial Ekonomi Kelautan dan Perikanan. 12(1): 75-91.

Sari, KR., Widyastutik. (2015). Faktor yang Mempengaruhi dan Estimasi Ekuivalen Tarif NTBs Ekspor Kayu Lapis Indonesia. Buletin IImiah Litbang Perdagangan. 9(1): 95-108.

Sohn, Chan-Hyun. (2005). Does the Gravity Model Explain South Korea's Trade Flows? Japanese Economic Review, Volume 56, Issues 4, pages 417-430.

Stern, R. \& B. Hoekman. (1988). The Service Sektor in Economic Structure and in International Transactions. in L. Castle and C. Findlay (eds.), Pacific Trade in Services. Sydney: Allen \& Unwin.

Tan, AK. (2012). Toward a Single Aviation Market in ASEAN: Regulatory Reform and Industry Challenges. Discussion Paper. Singapura: National University of Singapore.

Walsh, K. (2006). Trade in Services: Does Gravity Hold? A Gravity Model Approach to Estimating Barriers to Services. Institute for International Integration Studies (IIIS) Discussion Paper. No 183/October 2006.

Whalley, J. (2004). Assessing the Benefits to Developing Countries to Liberalisation in Services Trade. The World Economy, Vol.27 (8), pp.12231253. 
Whittle, C. (2012). Open Sky dan Maskapai Penerbangan Indonesia. Jurnal Prakarsa Infrastruktur Indonesia. Edisi 9 Januari 2012.

Widyastutik. (2016). Dampak Ekonomi Hambatan Regulasi Perdagangan Sektor Jasa Transportasi: Kasus ASEAN dan ASEAN's Dialogue Partner. Disertasi. Depok: UI.

Widyastutik, Nazara, S., Oktaviani, R., Simarmata, D. (2017). Trade Barier Elimination, Economics of Scale, and Market Competition: Computable General Equilibrium Model diunduh pada $5 \quad$ Mei 2019 (http://journal.uinjkt.ac.id/index.php/si gnifikan/article/view/52790029
Winchester, N. (2008). Is There Are Dirty Little Secret? Non Tariff Barriers and The Gain From Trade. Dunedin: University of Otago.

Woolridge. (2006). Introduction Econometric. Thomson SouthWestern.

Yeah, K.L., Yanagida, J., F., Yamauchi, H. (1994). Evaluation of External Market Effects and Government Intervention in Malaysia Agriculture Sector, A Computable General Equilibrium Framework. Agric Econ. 11(2-3), 237256. 
